\title{
Influence of low light intensity on growth and yield of four soybean cultivars during wet and dry seasons of Northeast Thailand
}

\author{
Anan Polthanee*, Khanistha Promsaena, Anucha Laoken \\ Department of Plant Science and Agricultural Resources, Faculty of Agriculture, Khon Kaen University, Khon Kaen, Thailand; \\ *Corresponding Author: panan@kku.ac.th
}

Received 28 September 2010; revised 23 February 2011; accepted 2 March 2011.

\begin{abstract}
Crop is commonly grown in intercrop combinations of which cereal/legumes are the most widespread in tropical countries. The availability of low light intensity due to shading is the critical factor in determining legume yield in intercropping. The experiment searches of better soybean cultivar for intercropping. A field experiment was conducted at the experimental farm of Khon Kaen University in 2005. The objectives of this study were to determine the influence of light regimes (30\% of normal light, $50 \%$ of normal light and normal light) on the growth and yield of four soybean cultivars (early, medium and late maturity) under artificial shading at $\mathbf{3 5}$ days after seeding until harvest in the wet and dry seasons. The results showed that grain yield was significantly $(p<0.05)$ decreased under the low light intensity at $30 \%$ of natural light both in wet and dry season. This was mainly due to low light intensity at $30 \%$ of natural light decreasing the number of pods per plant in the dry season. For cultivars, grain yield was significantly difference $(p<0.05)$ among cultivars both in the wet and dry seasons. The cultivar KKU 74 (medium maturity) gave maximum grain yield both in wet and dry season under the low light at $30 \%$ of natural light. The KKU 74 cultivar is better adapted to shading environment than other cultivars. This was due to the KKU 74 cultivar produced higher chlorophyll b concentration in leaves after the plant experienced to shading. This physiological character can be used for soybean breeding program in shading tolerance. Therefore, the cultivar KKU 74 had a higher potential yield advantage in intercropping systems in which low light intensity is a major limiting factor on grain yield.
\end{abstract}

Keywords: Chlorophyll Concentration; Shading; Soybean

\section{INTRODUCTION}

Intercropping can be used by small farmers primarily to increase the diversity of their products and the stability of their annual output through effective use of land and other resources [1,2].

Grain yield of soybean decreasing, when intercropped with maize has been reported [3-5]. The low yield in intercropped soybean as compared to monoculture is mainly due to shading resulting in weak plant growth [6-8].

The reduction in light reaching the legume canopy when intercropped with maize was about $30 \%-50 \%$ of the total incoming radiation and began around $30-35$ days after maize seeding [9-11].

The grain yield of soybean reduced under the low light because of reduction in dry matter production [12], total pod number per plant $[8,12,13]$ and thousand grains weight [5]. To obtain the maximum yield of the intercrop soybean under low light stress, selection of suitable soybean cultivar plays an important role for intercropping systems. The cultivars may respond to shading stress di- fferently in terms of growth and yield.

The objectives of this study were to determine the influence of light regimes (30\% of normal light, $50 \%$ of normal light and normal light) on the growth and yield of 4 soybean cultivars under artificial shading in the wet and dry seasons.

\section{MATERIALS AND METHODS}

\subsection{Establishment and Management}

The experiments were conducted in a field on welldrained (Oxic Paleustult) sandy loam soil at the experimental farm, Faculty of Agriculture, Khon Kaen University in the wet season (June-October 2005) and dry season (November 2005-February 2006). The four soybean cultivars (determined by growth habit) were; Nakhonsawan 1 (NKS 1), Chiangmai 60 (CM 60), Khon Kaen 
University 74 (KKU 74) and Ratchamongkol 1(RCM 1). They were seeded on 16 June 2005 in the wet season and on 9 November 2005 in the dry season.

Plot size was $6 \times 4$ meters, spaced $50 \times 20 \mathrm{~cm}$ between row and plants oriented on a south-north direction, and hand thinned to 2 plants per hill at 10 days after seeding. Preplant fertilizer grade 12-24-12 (N, $\mathrm{P}_{2} \mathrm{O}_{5}$, $\mathrm{K}_{2} \mathrm{O}$ ) was applied to rows at a rate of $156 \mathrm{~kg} / \mathrm{ha}$. Control of insects and weeds were given as needed during the growing season according to Department of Agriculture, Ministry of Agriculture and Cooperative Recommendation [14]. A sprinkler irrigation system was used in the dry season trial.

\subsection{Experimental Treatments}

The experiment was arranged in a split plot design with four replications. Light regimes as a main-plot consist of (i) shade for $70 \%$ of normal light, (ii) shade for $50 \%$ of normal light and (iii) no-shade control (normal light). Soybean cultivars as a sub-plot consist of the cultivar NKS 1 (early maturity), CM 60 (medium maturity), KKU 74 (medium maturity) and RCM 1 (late maturity). In the present study, shading conditions for the respective level of light intensity were created from 35 days after seeding until maturity. The early cultivar (NKS 1), medium cultivar (CM 60, KKU 74) and late cultivar (RCM 1) were subjected to shade stress at growth stages of R3, R2 and R1, respectively. The unshaded plot served as a control. The shade shelters were framed with polyvinylchloride pipe $5 \mathrm{~cm}$ in diameter, and covered with black shade cloth providing a $70 \%$ and $50 \%$ reduction of natural light. The shelter was $60 \mathrm{~m}$ in length, $4 \mathrm{~m}$ in width, and $2 \mathrm{~m}$ in height. The meteorological data of the experimental site in the wet and dry seasons are shown in Table 1 and Table 2.

\subsection{Measurements}

Eight plants were randomly selected outside the harvesting area to determine leaf area at 50\% flowering and to calculate the leaf area index (leaf area/ground area). At harvest, eight plants were randomly selected outside the harvesting area to record plant height, shoot dry weight, the number of pods per plant, the number of seeds per pod and 100 seeds weight. Grain yield was recorded from 50 random plants in the harvesting area.

Chlorophyll concentration was determined from leaves sampled from uppermost fully expanded main stem leaves at 30 day after shading by a spectrophotometric method [15].

Table 1. Meteorological data throughout the growing period (rainy season of 2005).

\begin{tabular}{|c|c|c|c|c|c|}
\hline \multirow{3}{*}{ Week } & \multirow{3}{*}{ Date } & \multirow{2}{*}{\multicolumn{2}{|c|}{ Average temperation }} & \multirow{3}{*}{$\begin{array}{c}\text { Total } \\
\text { Precipitation } \\
(\mathrm{mm})\end{array}$} & \multirow{3}{*}{$\begin{array}{c}\text { Total } \\
\text { Radiation } \\
\left(\mathrm{MJ} / \mathrm{m}^{2} / \mathrm{d}\right)\end{array}$} \\
\hline & & & & & \\
\hline & & $\operatorname{Max} .\left({ }^{\circ} \mathrm{C}\right)$ & Min. $\left({ }^{\circ} \mathrm{C}\right)$ & & \\
\hline 1 & 1 Jun.-7 Jun. & 34.1 & 26.1 & 1.3 & 132.3 \\
\hline 2 & 8 Jun.-14 Jun. & 33.5 & 26 & 4.3 & 95.6 \\
\hline 3 & 15 Jun.-21 Jun. & 34.7 & 25.5 & 64.3 & 122 \\
\hline 4 & 22 Jun.-28 Jun. & 32.1 & 24.5 & 50.2 & 91.3 \\
\hline 5 & 29 Jun.-5 Jul. & 32.5 & 24.8 & 54.9 & 96.4 \\
\hline 6 & 6 Jul.-12 Jul. & 33.5 & 24.6 & 16.4 & 110.1 \\
\hline 7 & 13 Jul.-19 Jul. & 34.8 & 24.7 & 21.3 & 127.2 \\
\hline 8 & 20 Jul.-26 Jul. & 31.1 & 24.6 & 41.4 & 82.3 \\
\hline 9 & 27 Jul.-2 Aug. & 32.2 & 24.8 & 1.7 & 95.2 \\
\hline 10 & 3 Aug.-9 Aug. & 32.6 & 25.1 & 14 & 96.3 \\
\hline 11 & 10 Aug.-16 Aug. & 31.6 & 24.6 & 15.2 & 89.5 \\
\hline 12 & 17 Aug.-23 Aug. & 32.1 & 24.1 & 50.5 & 89.5 \\
\hline 13 & 24 Aug.-30 Aug. & 33.6 & 24.2 & 53.1 & 108.1 \\
\hline 14 & 31 Aug.-6 Sep. & 31.7 & 24.3 & 95 & 101.4 \\
\hline 15 & 7 Sep.-13 Sep. & 29.9 & 24 & 140.6 & 74.7 \\
\hline 16 & 14 Sep.-20 Sep. & 31.2 & 24.1 & 33.1 & 90.1 \\
\hline 17 & 21 Sep.-27 Sep. & 32.5 & 24.5 & 103.6 & 88.5 \\
\hline 18 & 28 Sep.-4 Oct. & 32.6 & 25.1 & 5 & 114.5 \\
\hline 19 & 5 Oct.-11 Oct. & 31.6 & 24 & 3.1 & 113.5 \\
\hline 20 & 12 Oct.-18 Oct. & 32.7 & 24 & 0 & 122.4 \\
\hline 21 & 19 Oct.-25 Oct. & 32.4 & 22.8 & 0 & 109.5 \\
\hline 22 & 26 Oct.-31 Oct. & 32.8 & 22.9 & 0 & 99 \\
\hline
\end{tabular}


Table 2. Meteorological data throughout the growing period (dry season of 2005).

\begin{tabular}{|c|c|c|c|c|c|}
\hline \multirow{3}{*}{ Week } & \multirow{3}{*}{ Date } & \multirow{2}{*}{\multicolumn{2}{|c|}{ Average temperature }} & \multirow{3}{*}{$\begin{array}{c}\text { Total } \\
\text { Precipitation } \\
(\mathrm{mm})\end{array}$} & \multirow{3}{*}{$\begin{array}{c}\text { Total } \\
\text { Radiation } \\
\left(\mathrm{MJ} / \mathrm{m}^{2} / \mathrm{d}\right)\end{array}$} \\
\hline & & & & & \\
\hline & & $\operatorname{Max} .\left({ }^{\circ} \mathrm{C}\right)$ & $\operatorname{Mim} .\left({ }^{\circ} \mathrm{C}\right)$ & & \\
\hline 1 & 1 Nov. 05-7 Nov. 05 & 32.9 & 23.1 & 3.5 & 92.9 \\
\hline 2 & 8 Nov. $05-14$ Nov. 05 & 33.8 & 24.2 & 10.7 & 94.5 \\
\hline 3 & 15 Nov. 05-21 Nov. 05 & 31 & 21.4 & 0 & 98.1 \\
\hline 4 & 22 Nov. 05-28 Nov. 05 & 29.6 & 17.7 & 0 & 96.9 \\
\hline 5 & 29 Nov. 05-5 Dec. 05 & 32.5 & 21.1 & 0 & 95.2 \\
\hline 6 & 6 Dec. 05-12 Dec. 05 & 30 & 19.9 & 0 & 100.1 \\
\hline 7 & 13 Dec. 05-19 Dec. 05 & 26.6 & 14.9 & 0 & 98.9 \\
\hline 8 & 20 Dec. 05-26 Dec. 05 & 27 & 16.5 & 1 & 77.9 \\
\hline 9 & 27 Dec. 05-2 Jan. 06 & 31.4 & 19.3 & 0 & 99.9 \\
\hline 10 & 3 Jan. 06-9 Jan. 06 & 30.8 & 18.3 & 0 & 105.6 \\
\hline 11 & 10 Jan. 06-16 Jan. 06 & 32.8 & 16.9 & 0 & 109.7 \\
\hline 12 & 17 Jan. 06-23 Jan. 06 & 33.1 & 18.6 & 0 & 113.3 \\
\hline 13 & 24 Jan. 06-30 Jan. 06 & 29.9 & 15.9 & 0 & 113.4 \\
\hline 14 & 31 Jan. 06-6 Feb. 06 & 32.9 & 19.2 & 0 & 115.3 \\
\hline 15 & 7 Feb. 06-13 Feb. 06 & 29.5 & 18.8 & 6.4 & 93.3 \\
\hline 16 & 14 Feb.06-20 Feb. 06 & 32.8 & 21 & 13.4 & 105.4 \\
\hline 17 & 21 Feb.06-27 Feb. 06 & 34.2 & 21.6 & 0 & 125.8 \\
\hline
\end{tabular}

\section{RESULTS AND DISCUSSION}

\subsection{Growth}

\subsubsection{Leaf Area Index}

In general, leaf area index (LAI) was not significantly influenced by the shading treatments at 50\% flowering both in wet and dry seasons (Table 3). However, the LAI decreased, ranging from 4 to $7 \%$ under the low light intensities in the wet season but similarly to unshaded control in dry season trials. The results of the present study are in contrast with earlier report. Low light intensity increased the leaf area in potato [16] and Pongamia pinnata [17]. For cultivars, the LAI was significantly different $(\mathrm{p}<0.05)$ among soybean cultivars in both wet and dry seasons (Table 3 ). The cultivar RCM 1 gave the maximum LAI (6.3) in the wet season. The cultivar CM 60 gave the highest LAI (2.7) in the dry season. These results indicated that the late cultivar with longer vegetative growth had a higher LAI than the early cultivar in the wet season but not in the dry season.

\subsubsection{Plant Height}

The plant height was significantly influenced ( $\mathrm{p}<$ 0.05 ) by the shading treatments at harvest in the wet but not in the dry season trial (Table 3). The plant height increased, ranging from 10 to $24 \%$ under the low light in the wet season regarding shading level. In the present experiment the plant height was significantly different (p $<0.05$ ) among soybean cultivars in both wet and dry season (Table 3 ). The cultivar RCM 1 gave the highest plant height $(114 \mathrm{~cm})$ in the wet season, while the KKU
74 gave the maximum plant height $(53 \mathrm{~cm})$ in the dry season.This result indicated that soybean growth in the wet season gave higher plant height than in the dry season. This was due to light intensity in the wet season being lower than in the dry season. The cultivar RCM 1 gave the highest plant height in the wet season. This was due to the longer vegetative growth period of the late maturity cultivars.

In the present experiment, however, the cultivar RCM 1 (late maturity) and cultivar KKU 74 (medium maturity) did not show any significant difference in plant height in the dry season.

The plant height in rice increased by 31\% under low light intensity was reported by Jadhav [18]. In contrast, reduction on shoot length of Pongamia pinnata by $24 \%$ in shade has been reported [17].

\subsubsection{Shoot Dry Weight}

The shading treatments did not show any significant difference on the shoot dry weight of soybean at harvest (Table 3). However, the shoot dry weight decreased, ranging from $18 \%-23 \%$ and $15 \%$ - $32 \%$ under the low light intensities in the wet and dry season, respectively.

Shading decreased shoot dry weight of soybean compared with the unshaded control as reported earlier by Kakiuchi and Kobata [12, 13], Saito and Kato [19], and reduced dry matter yield in rice [20]. For cultivars, the shoot dry weight was significantly different $(\mathrm{p}<0.05)$ among soybean cultivars (Table 3 ). The cultivar RCM 1 produced the maximum shoot dry weight of $2288 \mathrm{~kg} \cdot \mathrm{ha}^{-1}$ in the wet season and $779 \mathrm{~kg} \cdot \mathrm{ha}^{-1}$ in the dry season. This 
Table 3. Influence of light intensity on leaf area index at 50\% flowering, plant height and shoot dry weight at harvest of soybean in wet and dry seasons 2005-2006.

\begin{tabular}{|c|c|c|c|c|c|c|c|c|c|}
\hline \multirow{2}{*}{ Cultivar } & \multicolumn{3}{|c|}{ Leaf area index } & \multicolumn{3}{|c|}{ Plant height $(\mathrm{cm})$} & \multicolumn{3}{|c|}{ Shoot dry weight (kg/ha) } \\
\hline & $100 \%$ & $50 \%$ & $30 \%$ & $100 \%$ & $50 \%$ & $30 \%$ & $100 \%$ & $50 \%$ & $30 \%$ \\
\hline \multicolumn{10}{|l|}{ Wet season } \\
\hline NKS 1 & 4.0 & 4.1 & 4.8 & 67.9 & 58.9 & 66.9 & 1139.6 & 961.4 & 1061.3 \\
\hline CM 60 & 5.8 & 6.2 & 4.1 & 83.6 & 92.5 & 102.9 & 2346.0 & 2247.5 & 1771.9 \\
\hline KKU 74 & 5.4 & 5.1 & 5.1 & 83.1 & 101.9 & 99.9 & 2164.4 & 2230.8 & 1771.9 \\
\hline RCM 1 & 6.8 & 5.9 & 6.2 & 94.0 & 108.5 & 138.8 & 2646.3 & 2036.9 & 2178.8 \\
\hline LSD (Shading) & & & & & 11.52 & & & & \\
\hline LSD (Cultivar) & & 1.44 & & & 22.27 & & & 1052.20 & \\
\hline Shading (S) & & NS & & & $* *$ & & & NS & \\
\hline Cultivar (C ) & & $* *$ & & & $* *$ & & & $* *$ & \\
\hline $\mathrm{C} \times \mathrm{S}$ & & NS & & & NS & & & NS & \\
\hline \multicolumn{10}{|l|}{ Dry season } \\
\hline NKS 1 & 2.0 & 1.9 & 2.0 & 33.7 & 35.1 & 31.1 & 489.4 & 390.6 & 444.1 \\
\hline CM 60 & 2.7 & 2.7 & 2.5 & 41.5 & 46.2 & 40.8 & 705.6 & 768.1 & 563.8 \\
\hline KKU 74 & 2.6 & 2.4 & 2.9 & 50.6 & 54.9 & 53.3 & 750.6 & 740.0 & 680.0 \\
\hline RCM 1 & 2.8 & 2.7 & 2.5 & 51.8 & 50.8 & 46.6 & 925.6 & 628.1 & 782.7 \\
\hline LSD (Cultivar) & & 0.50 & & & 6.64 & & & 20.36 & \\
\hline Shading (S) & & NS & & & NS & & & NS & \\
\hline Cultivar (C) & & $* *$ & & & $* *$ & & & $*$ & \\
\hline $\mathrm{C} \times \mathrm{S}$ & & NS & & & NS & & & NS & \\
\hline
\end{tabular}

was due to the cultivar RCM 1 having the highest leaf area index in comparison with the other cultivars. The cultivar RCM 1 had the longest interval for seeding days to flowering (data not shown).

\subsection{Yield Components}

\subsubsection{Number of Pods per Plant}

The number of pods per plant was significantly influenced by the shading treatment in wet but not in dry season trials (Table 4). The number of pods per plant decreased by $32 \%$ and $14 \%$ under low light intensity at $30 \%$ and $50 \%$ of natural light, respectively, in the wet season. For the dry season, the number of pods per plant reduced by $21 \%$ and $17 \%$ under the low light intensities at $30 \%$ and $50 \%$ of natural light, respectively. Shading reduced the number of pods per plant for soybean as reported by Kurosaki and Yumoto [21] and Kakiuchi and Kobata [12,13]. In terms of cultivar, the number of pods per plant was significantly different $(p<0.05)$ among soybean cultivars in wet and dry season (Table 4). The cultivar CM 60 (medium maturity) produced the maximum number of pods per plant (92 pods.plant ${ }^{-1}$ ) in the wet season and the cultivar RCM 1 (late maturity) gave the highest number of pods per plant (49 pods·plant ${ }^{-1}$ ) in the dry season. This result indicates that although the medium and late cultivars were subjected to shading for longer than the early cultivars, the potential advantage to produce the number of pods per plant was obtained for the longer growth cycle cultivar. Considering shading regime, the cultivar CM 60 gave the maximum number of pods per plant under the low light at $30 \%$ and $50 \%$ of natural light in the wet season, while the cultivar RCM 1 gave the highest number of pods per plant under low light at $30 \%$ and $50 \%$ of natural light in the dry season.

\subsubsection{Number of Seeds per Pod}

The number of seeds per pod was significantly influenced $(p<0.05)$ by the shading treatment in dry season but not in wet season (data not shown). The number of seeds per pod decreased by $7 \%$ and $8 \%$ under low light intensities at $30 \%$ and $50 \%$ of natural light, respectively in the dry season. This agrees with the work done by Egli [22]. In the wet season, the number of seeds per pod was similarly under low light at 30\% and 50\% of natural light in comparison with normal light. The number of seeds per pod was not influenced by the shade treatment as reported by Kakiuchi and Kobata [12,13].

\subsubsection{Seed Weight}

The shading treatment had no influence on the 100 seeds weight of soybean both in wet and dry season trials (Table 4). There was a significant difference of 100 seeds weight among cultivars (Table 4). The results of the present study are in agreement with earlier reports by Kakiuchi and Kobata [12,13]. In contrast, shading reduced seed size as reported by Egli [22].

\subsubsection{Grain Yield}

The grain yield was significantly decreased $(\mathrm{p}<0.05)$ under low light at $30 \%$ of natural light both in wet and dry seasons, but not at 50\% of natural light (Table 4). The grain yield reduced by $25 \%$ in the wet season and $37 \%$ in the dry season under low light at $30 \%$ of natural light and reduced by $10 \%$ and $27 \%$ in wet and dry seasons, respectively, under shading at $50 \%$ of natural light. This was due to a significant decrease in the number of pods per plant in the wet season and the number of seeds per pod in the dry season at $30 \%$ of natural light. 
Table 4. Influence of light intensity on yield and yield components of soybean in wet and dry seasons 2005-2006.

\begin{tabular}{|c|c|c|c|c|c|c|c|c|c|}
\hline \multirow{2}{*}{ Cultivar } & \multicolumn{3}{|c|}{ Pod number } & \multicolumn{3}{|c|}{100 seeds weight (gm) } & \multicolumn{3}{|c|}{ Yield (ton/ha ${ }^{-1}$ ) } \\
\hline & $100 \%$ & $50 \%$ & $30 \%$ & $100 \%$ & $50 \%$ & $30 \%$ & $100 \%$ & $50 \%$ & $30 \%$ \\
\hline \multicolumn{10}{|l|}{ Wet season } \\
\hline NKS 1 & 44.2 & 44.6 & 43.5 & 21.6 & 21.2 & 21.0 & 2.7 & 2.7 & 2.6 \\
\hline CM 60 & 114.4 & 99.2 & 62.4 & 14.9 & 15.9 & 15.6 & 4.9 & 4.9 & 3.1 \\
\hline KKU 74 & 68.1 & 48.1 & 44.1 & 21.1 & 19.8 & 20.5 & 4.6 & 4.0 & 3.2 \\
\hline RCM 1 & 74.6 & 67.0 & 54.8 & 18.8 & 18.6 & 18.9 & 4.2 & 3.2 & 2.9 \\
\hline LSD (Shading) & & 16.13 & & & & & & 0.88 & \\
\hline LSD (Cultivar) & & 16.60 & & & 1.19 & & & 0.88 & \\
\hline Shading (S) & & $*$ & & & NS & & & * & \\
\hline Cultivar (C ) & & $* *$ & & & $* *$ & & & $* *$ & \\
\hline $\mathrm{C} \times \mathrm{S}$ & & NS & & & NS & & & NS & \\
\hline \multicolumn{10}{|l|}{ Dry season } \\
\hline NKS 1 & 29.9 & 21.5 & 19.5 & 23.7 & 23.8 & 23.9 & 2.0 & 1.4 & 1.3 \\
\hline CM 60 & 48.1 & 41.8 & 33.2 & 16.9 & 17.0 & 16.3 & 2.6 & 1.8 & 1.4 \\
\hline KKU 74 & 36.7 & 32.0 & 31.8 & 20.5 & 19.2 & 18.2 & 2.3 & 1.8 & 1.7 \\
\hline RCM 1 & 52.2 & 45.6 & 47.6 & 18.6 & 18.4 & 18.8 & 2.9 & 2.1 & 1.6 \\
\hline LSD (Shading) & & & & & & & & 0.68 & \\
\hline LSD (Cultivar) & & 10.31 & & & 1.56 & & & 0.27 & \\
\hline Shading (S) & & NS & & & NS & & & $* *$ & \\
\hline Cultivar (C ) & & $* *$ & & & $* *$ & & & $*$ & \\
\hline $\mathrm{C} \times \mathrm{S}$ & & NS & & & NS & & & NS & \\
\hline
\end{tabular}

That shading decreased seed yield of soybean has been earlier reported [12,13,21,22]. For cultivars, grain yield was significantly different $(\mathrm{p}<0.05)$ among soybean cultivars (Table 4 ). The grain yield reduced by 6\% - $37 \%$ in the wet season and $25 \%-44 \%$ in the dry season at $30 \%$ of natural light, depending on cultivar. The cultivars NKS 1 and KKU 74 gave minimum yield reduction by $6 \%$ and $25 \%$ in the wet and dry seasons, respectively, at $30 \%$ natural light. With shading at $50 \%$ of natural light, the cultivars CM 60 and KKU 74 gave minimum yield reduction by $0.1 \%$ and $23 \%$ in wet and dry seasons, respectively. In terms of potential yields advantage, the cultivar KKU 74 gave maximum grain yields of 3.2 and 1.7 ton $\mathrm{ha}^{-1}$ in wet and dry seasons, respectively under shading at $30 \%$ of natural light, while the cultivar CM 60 produced the highest grain yield of 4.9 ton $\mathrm{ha}^{-1}$ in the wet season and the cultivar RCM 1 gave the maximum grain yield of $2.1 \mathrm{ton}^{\mathrm{h}} \mathrm{a}^{-1}$ in the dry season under shading at $50 \%$ of natural light.

These results indicate that the cultivar KKU 74 has a higher potential yield advantage when grown in artificial shade than other cultivars. Further research under actual field conditions of corn-soybean intercropping systems using four soybean cultivars should be investigated under the competition for light, nutrients and water between the two crops.

\subsubsection{Chlorophyll Concentration}

The total chlorophyll content in leaves was not affected by the shading treatment in both wet and dry seasons. However, the total chlorophyll content tended to increase in the shaded treatments (data not shown). Increase of total chlorophyll content in leaves by shade was also reported by Naidy and Swamy [17] and Mut- huchelian et al. [23]. The increased pigment content of shade leaves has been attributed to the increase in the number and size of chloroplasts, the amount of chlorophyll per chloroplast and better grana development [24]. In general, the shade leaves had a lower photosynthetic rate due to the lower activity of photosynthetic enzymes, RuBP carboxylase [25]. In the present experiment, KKU 74 cultivar gave the highest chlorophyll b $\left(2.18 \mathrm{mg} / \mathrm{cm}^{2}\right)$ concentration in leaf after the plant experienced to shading 30 days (data not shown). In addition, the increase in chlorophyll b concentration before soybean experienced to shading (35 days after seeding) and after shading 30 days in KKU 74, NKS 1, CM 60 and RCM 1 cultivars was about $66 \%, 63 \%, 56 \%$ and $42 \%$, respectively. This associated with the adaptation of leaves to the low light environment to intercept more light energy [26,27], or with a decreased chlorophyll degradation rate [28]. This physiological character can be used as criteria for soybean breeding program in shading tolerance.

\subsubsection{Relationship between Shoot Dry Weight and Yield}

Shoot dry weight is a dominant factor for yield. The higher shoot dry weight resulted to the higher in branch number and consequently pod number per plant. In the present experiment, soybean grown in wet season produced higher seed yield than in the dry season. This was due to shoot dry weight of soybean in wet season was higher than in the dry season (Figure 1). The days of seeding to flowering of soybean in wet season were longer 20 days than in the dry season.

In the present experiment, cultivar differed in response of yield to shading, the KKU 74, CM 60 and RCM 1 gave a similar in seed yield, but the three of soy- 

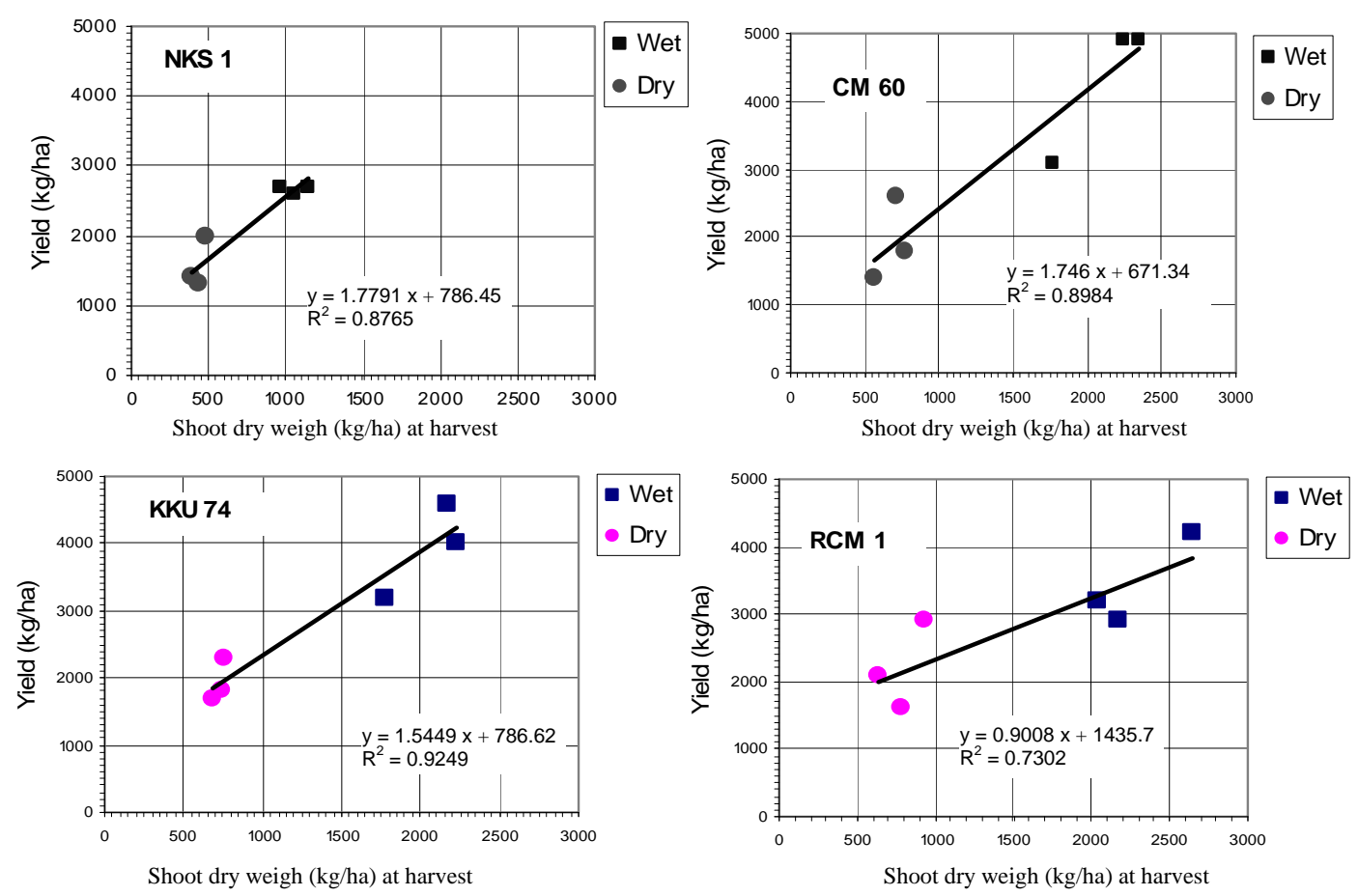

Figure 1. The relationship between shoot dry weight and grain yield of 4 cultivars.
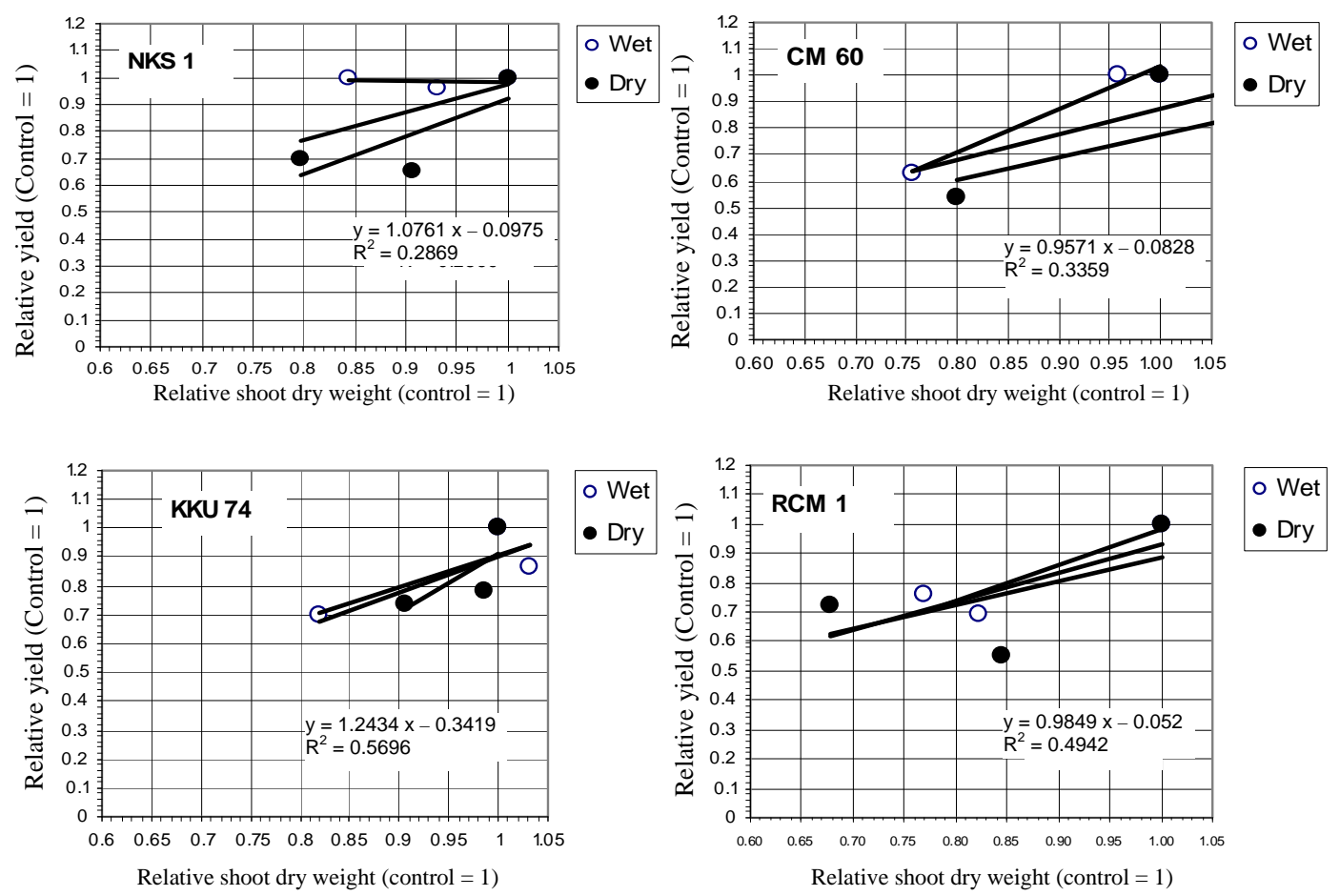

Figure 2. The relationship between relative shoot dry weight and grain yield of 4 cultivars.

bean cultivars were significantly higher in seed yield then NKS 1 cultivar. This was due to the three soybean cultivars longer vegetative growth period than NKS 1 cultivar. In term of adaptation, the KKU 74 cultivar seems to be better adapted to shading stress than the other cultivars (Figure 2). Yield reduction due to shading in comparison with control in this cultivar was lower than that of other cultivars (Figure 2). 


\section{REFERENCES}

[1] Roy, R.P., Sharam, H.M. and Thakur, H.C. (1981) Studies on intercropping in long-duration pigeonpea on sandy loam soil of North Bihar. Indian Journal of Agronomy, 26, 72-82.

[2] Faris, M.H., Burity, H.A., Reis, D.V.D. and Mafra, R.C. (1983) Economic analysis of bean and maize system in monoculture vs. associated cropping. Field Crop Research, 1, 319-335.

[3] Huges, H.D. and Metcalfe, D.S. (1972) Crop production. 3rd Edition, Macmillan Publishing, New York.

[4] Odango, J.C.W., Veresoglo, D.S. and Sfica, A.G. (1990) Effects of population density, nitrogen fertilization and inoculation of the yield of intercropped maize and soybean. Field Crop Abstract.

[5] Hayder, G., Mumraz, S.S., Khan, A. and Khan, S. (2003) Maize and soybean intercropping under various levels of soybean seed rates. Asian Journal of Plant Sciences, 2, 339-341. doi:10.3923/ajps.2003.339.341

[6] Ahmed, S. and Rao, M.R. (1982) Performance of maize-soybean intercrop combinations in the tropics: Results of a multi-location study. Field Crop Research, 5, 147-161. doi:10.1016/0378-4290(82)90015-6

[7] Nizamani, M.I.F. (1986) Yield performance of maize intercropping system with soybean under various fertility levels. Master's Thesis, Sindh Agriculture University, Tandojam.

[8] Panhwar, M.A., Mempn, F.H., Kalhoro, M.A. and Somro, M.I. (2004) Performance of maize in intercropping system with soybean under different planting patterns and nitrogen levels. Journal of Applied Science, 4, 201-204. doi:10.3923/jas.2004.201.204

[9] Polthanee, A. and Changsri, R. (1999) Effect of planting dates of mungbean on growth and yield in corn mungbean relay cropping under rainfed conditions in an upland area of Northeastern Thailand. Thai Journal of Agricultural Science, 32, 187-196.

[10] Polthanee, A. and Treloges, V. (2002) Growth and yield of mungbean cultivars in mungbean-corn relay intercropping systems. Journal of International Society for Southeast Asian Agricultural Sciences, 8, 1-14.

[11] Polthanee, A. and Treloges, V. (2003) Growth, yield and land use efficiency of corn and legumes grown under intercropping systems. Plant Production Science, 6, 139-146. doi:10.1626/pps.6.139

[12] Kakiuchi, J. and Kobata, T. (2004) Shading and thinning effects on seed and shoot dry matter increase in determinate soybean during the seed-filling period. Agronomy Journal, 96, 398-405 doi:10.2134/agronj2004.0398

[13] Kakiuchi, J. and Kobata, T. (2006) The relationship between dry matter increase of seed and shoot during the seed-filling period in three kinds of soybeans with different growth habits subjected to shading and thinning. Plant Production Science, 9, 20-27. doi:10.1626/pps.9.20

[14] Department of Agriculture, Ministry of Agriculture and Cooperative Recommendation (2001) Good agricultural
Bangkok.

[15] Moran, R. (1981) Formulae for determination of chlorophyll pigments extracted with $\mathrm{N}$, N-Dimethyl formide. Plant Physiology, 69, 1376-1381. doi:10.1104/pp.69.6.1376

[16] Singh, L. (1988) Adaptation and yield of potato under low light intensity. Indian Journal of Plant Physiology, 31, 114-116.

[17] Naidu, C. V. and Swamu, P. M. (1993) Effect of shade on growth, biomass production and associated physiological parameters in Pongamia Pinnata (Linn.) Pierre. Indian Journal of Plant Physiology, 37, 212-214.

[18] Jadhav, B.B. (1987) Effect of partial shading on the yield of rice. Indian Journal of Agricultural Science, 57, 515-516.

[19] Saito, M. and Kato, T. (1994) Effects of low temperature and shade on relationships between nodulation vesicular-arbuscular mycorrhizal infection, and shoot growth of soybean. Biology and Fertility of Soil, 17, 206-211. doi:10.1007/BF00336324

[20] Singh, V.P., Dey, S.K. and Murthy, K.S. (1988) Effect of low light stress on growth and yield of rice. Indian Journal of Plant Physiology, 31, 84-91.

[21] Kurosaki, H. and Yumoto, S. (2003) Effects of low temperature and shading during flowering on the yield components in soybeans. Plant Production Science, 6, 17-23. doi:10.1626/pps.6.17

[22] Egli, D.B. (1977) Cultivar maturity and response of soybean to shade stress during seed filling. Field Crops Research, 52, 1-8. doi:10.1016/S0378-4290(97)00005-1

[23] Muthuchelian, K., Paliwan, K. and Gnanam, A. (1989) Influence of shading on net photosynthesis and transpiration rates, stomatal diffusive resistance, nitrate reductase and biomass productivity of a woody legume tree species. The Proceedings of the Indian Academy of Sciences, 99, 539-546.

[24] Boardman, N.K. (1977) Comparing photosynthesis of sun and shade plants. Annual Review of Plant Physiology, 28, 355-377. doi:10.1146/annurev.pp.28.060177.002035

[25] Usuda, H., Ku, S.B.M. and Edwards, G.E. (1985) Influence of light intensity during growth on photosynthesis and activity of several key photosynthetic enzymes in a C4 plant (Zea mays). Physiologia Plantarum, 63, 65-67. doi:10.1111/j.1399-3054.1985.tb02819.x

[26] Barker, J. (1985) Thylakoid membrane structure and organization of electron transport components. In: Barker, J. and Baker, R. Eds., Photosynthetic Mechanisms and the Environment, Elsevier, Amsterdam, 91-134.

[27] Zhao, D. and Oosterhuis, D. (1998) Cotton responses to shade at different growth stages: Nonstructural carbohydrate composition. Crop Science, 38, 1196-1203. doi:10.2135/cropsci1998.0011183X003800050014x

[28] Hale, M.G. and Orcutt, M.M. (1987) Irradiation stress. In: Hale, M.G. and Orcutt, D.M. Eds., The Physiology of Plants Under Stress, John Wiley and Sons, New York, 109-115. 